\title{
Evolution of organic and inorganic components of aerosol during a Saharan dust episode observed in the French Alps
}

\author{
G. Aymoz ${ }^{1}$, J.-L. Jaffrezo ${ }^{1}$, V. Jacob ${ }^{2}$, A. Colomb ${ }^{2, *}$, and Ch. George ${ }^{3}$ \\ ${ }^{1}$ Laboratoire de Glaciologie et Géophysique de l'Environnement (LGGE-CNRS), 54 rue Molière, 38402 Saint Martin \\ D'Hères Cedex, France \\ ${ }^{2}$ Groupe de Recherche en Environnement et Chimie Appliquée (GRECA) IUT de Chimie, UJF, 39-41 Bd Gambetta, 38000 \\ Grenoble, France \\ ${ }^{3}$ Laboratoire d'Application de la Chimie à l'Environnement (UCLB-CNRS), 43 boulevard du 11 Novembre 1918, F-69622 \\ Villeurbanne, France \\ *now at: Max Planck Institut für Chemie, Postfach 3060, 55020 Mainz, Germany
}

Received: 1 March 2004 - Published in Atmos. Chem. Phys. Discuss.: 12 July 2004

Revised: 30 September 2004 - Accepted: 5 December 2004 - Published: 9 December 2004

\begin{abstract}
A Saharan dust event was observed in a rural area in the Maurienne Valley (French Alps) in summer 2000. Detailed data on $\mathrm{PM}_{10}$, particle numbers, and aerosol chemistry (ionic species and Elemental Carbon (EC) and Organic Carbon $(\mathrm{OC})$ ) are presented. The comparative evolutions of particle numbers and chemistry (calcium, sodium, and sulfate) show that the overall period included two episodes of dust particles with very distinct chemistry, followed by an episode with a large increase of the concentrations of species with an anthropogenic origin. The overall data set does not indicate large interactions between the dust particles and compounds from anthropogenic origin (sulfate, nitrate) or with organic carbon, all of these species showing very low concentrations. Simplistic calculations indicate that these concentrations are consistent with our current knowledge of adsorption processes of gases on mineral dust in a clean air mass.
\end{abstract}

\section{Introduction}

Atmospheric dust aerosol load plays an important role in the Earth's climatic system. The Sahara is among the world largest source of dust aerosol (Swap et al., 1996) and a large part of the northern hemisphere is influenced by these emissions. Frequent dust inputs are experienced in southern Europe, for example in Spain (Rodriguez et al., 2001), but events are also seen up north, i.e. in the United Kingdom (Ryall et al., 2002). The frequency of dust events varied over the last decades (Goudie and Middleton, 2001) and De

Correspondence to: J.-L. Jaffrezo

(jaffrezo@lgge.obs.ujf-grenoble.fr)
Angelis and Gaudichet (1991) showed that these inputs increased over some parts of Europe between 1970 and 1985, as recorded in an ice core drilled in the Mont-Blanc area.

Goudie and Middleton (2001) reviewed the knowledge about global impact and environmental changes due to atmospheric Saharan dust inputs. These inputs are characterized by a large mass of particles leading, among other, to a dramatic increase of the $\mathrm{PM}_{10}$ load at ground level. Dust particles can react with different species, including those of anthropogenic origin (Usher et al., 2003). These exchanges can affect optical properties, size distribution and chemical composition of aerosol. Data on the increase of nitrate and sulfate associated with mineral dust during transport show that heterogeneous reactions can take place onto mineral dust surface. These interactions become well known and documented (Schurath and Neumann, 2003). Further, ozone decomposition on mineral dust is altering the surface of dust particles (Dhandapani and Oyama, 1997; Ouerdeni et al., 1996), potentially influencing interactions with other trace gases (Hanisch and Crowley, 2003a).

However, little is known about the interactions between dust aerosol and organic compounds or elemental carbon. Li et al. (2001) presented a laboratory study focussed on the heterogeneous reactions of some volatile organic compounds (VOCs) on crustal elements (see also Goss, 1992; Goss and Heisenreich, 1996) and demonstrated the possible impact of these reactions on the $\mathrm{HO}_{\mathrm{x}}$ budget in the lower troposphere. Field investigations on such chemical interactions are not numerous. In the framework of the Saharan Dust Experiment (SHADE), no carbonaceous matter was detected in dust samples (Formenti et al., 2003). Conversely, one result of the ACE ASIA program (Huebert et al., 2003) was that air pollution modifies dust aerosol in many ways, by adding acidic

(C) 2004 Author(s). This work is licensed under a Creative Commons License. 
gases, toxic materials, and elemental carbon to the mineral particles, potentially changing their impact on climate and human health (Chuang et al., 2003). Therefore, our current knowledge about interactions between dust aerosol and species emitted by human activities is still fragmentary, especially for organic compounds.

One further concern about these interactions is related to the regulation of $\mathrm{PM}_{10}$ levels. In Europe, the Air Quality Directive (Directive 1999/30/EC) sets a threshold value of $20 \mu \mathrm{g} \mathrm{m}^{-3}$ for $\mathrm{PM}_{10}$ annual mean, to be accomplished in the European Community by 2010 , with a daily value of $50 \mu \mathrm{g}$ $\mathrm{m}^{-3}$ not exceeded more than 7 days per year. Daily values exceeding $50 \mu \mathrm{g} \mathrm{m}^{-3}$ should not be taken into account if the aerosol has a natural origin. Nevertheless, particles in these disregarded cases can include an unknown fraction of material with an anthropogenic origin, with potential impacts on human health. The number of such cases is far from negligible with, for example, about 4-7 days a year between 1996 and 1999 in Spain (Rodriguez et al., 2001).

This paper presents detailed aerosol chemistry for a Saharan dust episode observed during an intensive field campaign in the French Alps in summer 2000. Parallel sampling for particle number concentrations and chemical analyses (ionic and carbonaceous species) on a short time scale brings in information on the evolution of the characteristics of the dust episode, and on interactions between species of anthropogenic origin and mineral dust.

\section{Experimental}

\subsection{Sampling site}

The data discussed in this paper were obtained in the framework of the POVA (Pollution des Vallées Alpines) program (Jaffrezo et al., $2004{ }^{1}$ ), dedicated to air quality studies in two French alpine valleys. An intensive field sampling took place in the Maurienne Valley (Fig. 1), between 22 and 29 August 2000. Results presented here were obtained in a rural area $1 \mathrm{~km}$ away from the village of Sollières $(1340 \mathrm{~m}$ above sea level, 170 inhabitants), in the upper part of the valley. This valley is characterised by important human activities in its lower part, with several industries and intense international heavy duty traffic between France and Italy under the Tunnel du Fréjus. The upper part of the valley is less densely populated and more agricultural, with Sollières located $20 \mathrm{~km}$ away from the entrance of the Tunnel du Fréjus.

\footnotetext{
${ }^{1}$ Jaffrezo, J.-L., Albinet, A., Aymoz, G., Besombes, J.-L., Chapuis, D., Jambert, C., Jouve, B., Leoz-Garziandia, E., Marchand, N., Masclet, P., Perros, P. E., and Villard, H.: The program POVA "Pollution des Vallées Alpines": general presentation and some highlights, to be submitted to Atmos. Chem. Phys. Discuss., 2004.
}

\subsection{Samplings and analysis}

Several sampling and measurements were performed during the whole week. $\mathrm{PM}_{10}$ measurements were performed with a TEOM (heated at $50^{\circ} \mathrm{C}$ ) with $15 \mathrm{~min}$ time resolution. Particles number concentrations were measured with a laser particle counter (Malvern MPC 301X/501X), also with a time resolution of $15 \mathrm{~min}$. Aerosols were classified in 4 size ranges (with limits at $0.3-0.5,0.5-1,1-5$ and $>5 \mu \mathrm{m}$ for the diameters). The upward straight air intake (5 mm ID) was $90 \mathrm{~cm}$ long, and sampling took place at a flow rate of $2.831 \mathrm{~min}^{-1}$. This led to approximate inlet efficiency higher than $90 \%$ for particles of $15 \mu \mathrm{m}$ (aerodynamic diameter).

Sampling for ionic analyses was performed on Teflon Zefluor filters ( $1 \mu \mathrm{m}$ porosity), on a 3-h basis during the day (08:00-20:00 LT), 4-h basis during the night. Filters were pre-washed with methanol (Baker, C-MOS grade) in order to lower the blanks levels. Sampling for analyses of carbonaceous matter (Organic Carbon (OC) and Elemental Carbon (EC)) was performed on quartz Whatman QMA filters, on a 6-h basis. Filters were pre-fired $2 \mathrm{~h}$ at $800^{\circ} \mathrm{C}$ in order to lower the blank levels. Flow rates for both sampling were $1.5 \mathrm{~m}^{3} \mathrm{~h}^{-1}$, with $47 \mathrm{~mm}$ open-face filter-holders located about $3 \mathrm{~m}$ above ground. Filters were changed manually and field blanks were collected daily. Exposed Teflon filters were stored in air tight glass bottles. Exposed quartz filters were stored in Petri-slides wrapped in aluminium foil and placed in sealed polyethylene bags. All filters were stored at $-4^{\circ} \mathrm{C}$ until their analyses.

Teflon filters were analyzed for soluble ionic components with ionic chromatography in a class 10000 clean room. All handling procedures were taking place under a class 100 laminar flow hood. Filters were extracted for $10 \mathrm{~min}$ in their storage bottle using $0.8 \mathrm{ml}$ of methanol (Baker C-MOS grade) in order to first wet the Teflon filters, followed with $9.2 \mathrm{ml}$ of Milli-Q water. Cations $\left(\mathrm{Na}^{+}, \mathrm{NH}_{4}^{+}, \mathrm{K}^{+}, \mathrm{Mg}^{2+}, \mathrm{Ca}^{2+}\right)$ were analyzed with a Dionex 100 chromatograph, using a CS12 column. Anions $\left(\mathrm{Cl}^{-}, \mathrm{NO}_{3}^{-}, \mathrm{SO}_{4}^{2-}\right.$ and a suite of organic acids) were analyzed with a Dionex 500, using an AS11 column. These analyses are described in details in Jaffrezo et al. (1998) and Ricard et al. (2002).

Analyses for OC and EC were performed with a thermooptical technique with correction of pyrolysis by laser transmission (the TOT method), on a Sunset Lab analyzer (Birch and Carry, 1996). The temperature ramp used four steps up to $870^{\circ} \mathrm{C}$ under pure helium for the quantification of $\mathrm{OC}$, and four steps up to $900^{\circ} \mathrm{C}$ with a mixture of $98 \% \mathrm{He}+2 \% \mathrm{O}_{2}$ for that of EC.

The arithmetic average values obtained for the blank filters were subtracted from concentrations of actual samples to obtain atmospheric concentrations. For most chemical species, concentrations in blank filters represented $10 \%$ at most of that in exposed filters. 


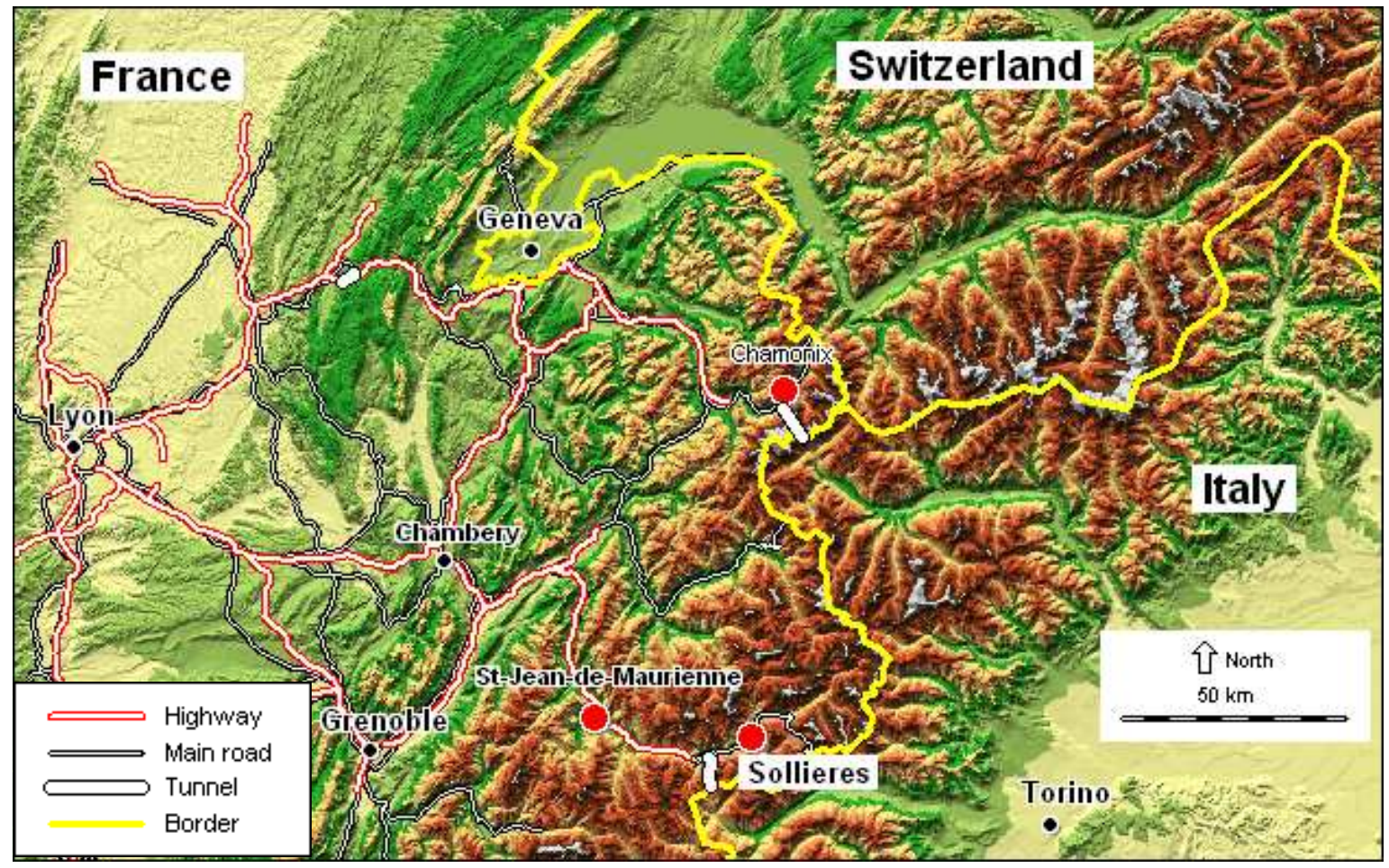

Fig. 1. Map of the Alpine area of the POVA program, with the location of the sampling site in Sollières.

\section{Results and discussion}

\subsection{The dust event: size and mass of the aerosol}

The meteorological situation during the early part of the experiment was classical for the summer season in the area, with marked diurnal temperature cycles between $5^{\circ} \mathrm{C}$ at night, up to $30^{\circ} \mathrm{C}$ during the day. Very few clouds where seen and no precipitation was recorded during the whole period. The wind direction pattern inside the valley was clearly dominated by diurnal changes between upslope (i.e. from the west, during the day) and down slope (at night) directions, driven by thermal heating. The wind speed was higher during the day than at night, but generally stayed below $4 \mathrm{~ms}^{-1}$. This situation changed on 26 and 27 August with a strong input of south wind reaching the valley floor on the morning of 26 August, lasting till late on 27 August. Visual observation at ground indicated a highly turbid atmosphere at that time, persisting till late the next day. Afterwards, the situation returned to the previous pattern of valley winds.

Figure 2 presents the evolutions of $\mathrm{PM}_{10}$ and particle number concentrations for the whole sampling week. $\mathrm{PM}_{10}$ concentrations slowly increased during the first part of the experiment (on 22-26 August with daily averages in the range 20$30 \mu \mathrm{g} \mathrm{m}^{-3}$, and pronounced diurnal variations with maxima during late afternoon or early evening. A very large increase in the $\mathrm{PM}_{10}$ concentrations took place in the late morning of
26 August, coincident with the change to south winds observed at ground. It happened in two distinct parts, the first one peaking between 11:30 and 14:00 LT. During the second part of this $\mathrm{PM}_{10}$ increase, hourly averages reached up to $285 \mu \mathrm{g} \mathrm{m}^{-3}$ at 19:00 LT. Afterwards, the $\mathrm{PM}_{10}$ concentrations decreased back to lower levels, reached at 08:00 LT on 27 August. The increase in $\mathrm{PM}_{10}$ was very well correlated with the changes in the concentrations of particles in the super micron channels $(\mathrm{d}>5 \mu \mathrm{m}$, and $1 \mu \mathrm{m}>\mathrm{d}>5 \mu \mathrm{m})$. Conversely, the evolution of the concentrations of the smaller particles $(0.3 \mu \mathrm{m}>\mathrm{d}>0.5 \mu \mathrm{m})$ was not linked to the evolution of the $\mathrm{PM}_{10}$ concentrations.

These high $\mathrm{PM}_{10}$ concentrations, along with large number of super micron particles, high atmospheric turbidity and south winds at ground level are characteristic of an input of Saharan dust into the area. This hypothesis is also supported by a SeaWifs picture (http://www.gsfc.nasa.gov/ indepth/photos_earth2000_p2.html; Fig. 3) showing a large dust cloud over the Mediterranean Sea on 25 August, extending from the Canaries Island to Sicily. Further, 3-day HYSPLIT air masses back trajectories (http://www.arl.noaa. gov/ready/hysplit4.html) arriving on site on midday on 26 August at levels of 1000 and $1500 \mathrm{~m}$ above ground indicate an origin of air masses from Northern Algeria, from regions above $30^{\circ} \mathrm{N}$ (Fig. 4).

A very different behavior is observed for the evolution of the particle number concentrations in the smaller size range 

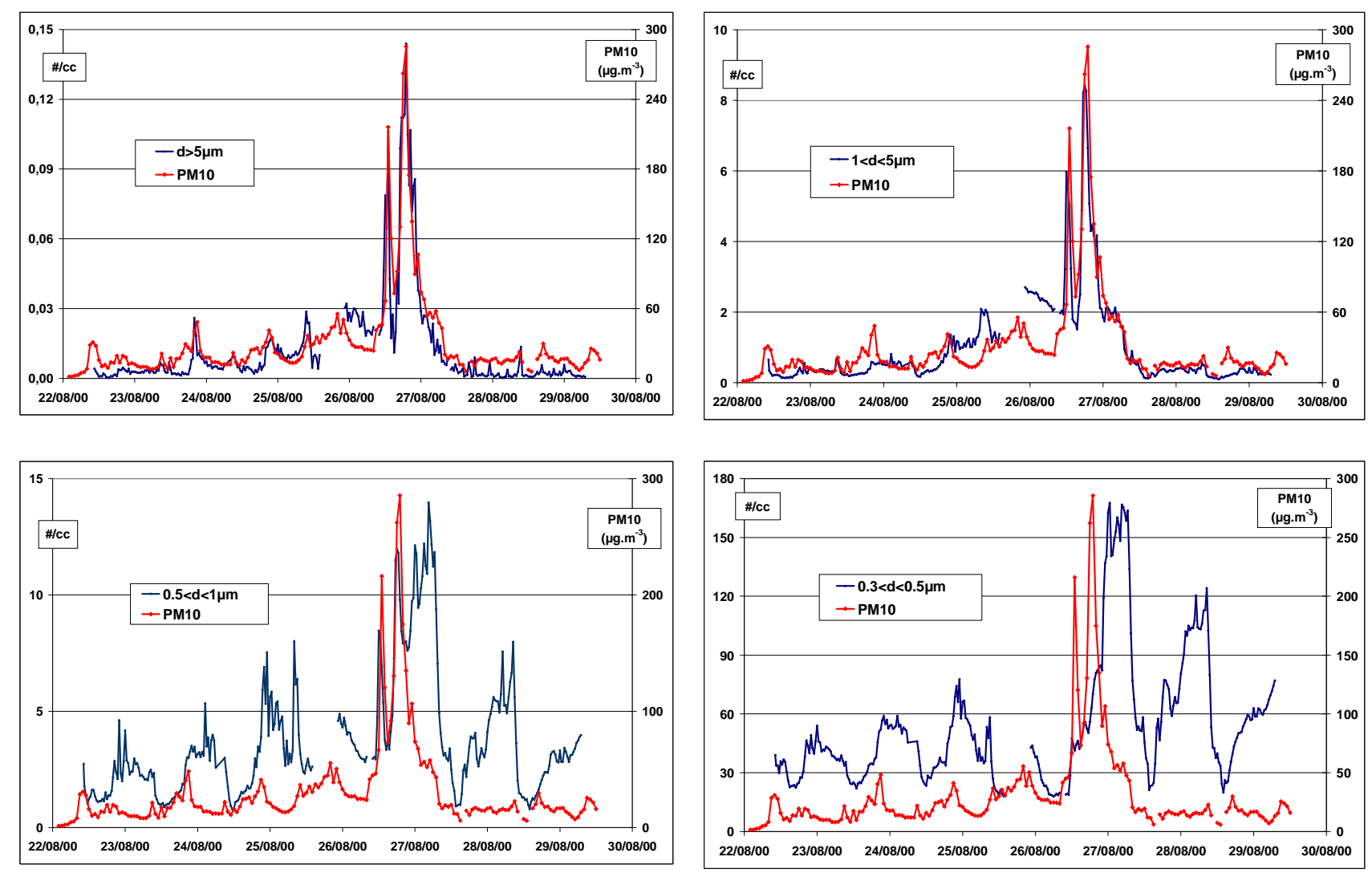

Fig. 2. Evolution of the $\mathrm{PM}_{10}$ concentration during the sampling week, together with particle number concentrations in 4 size ranges.

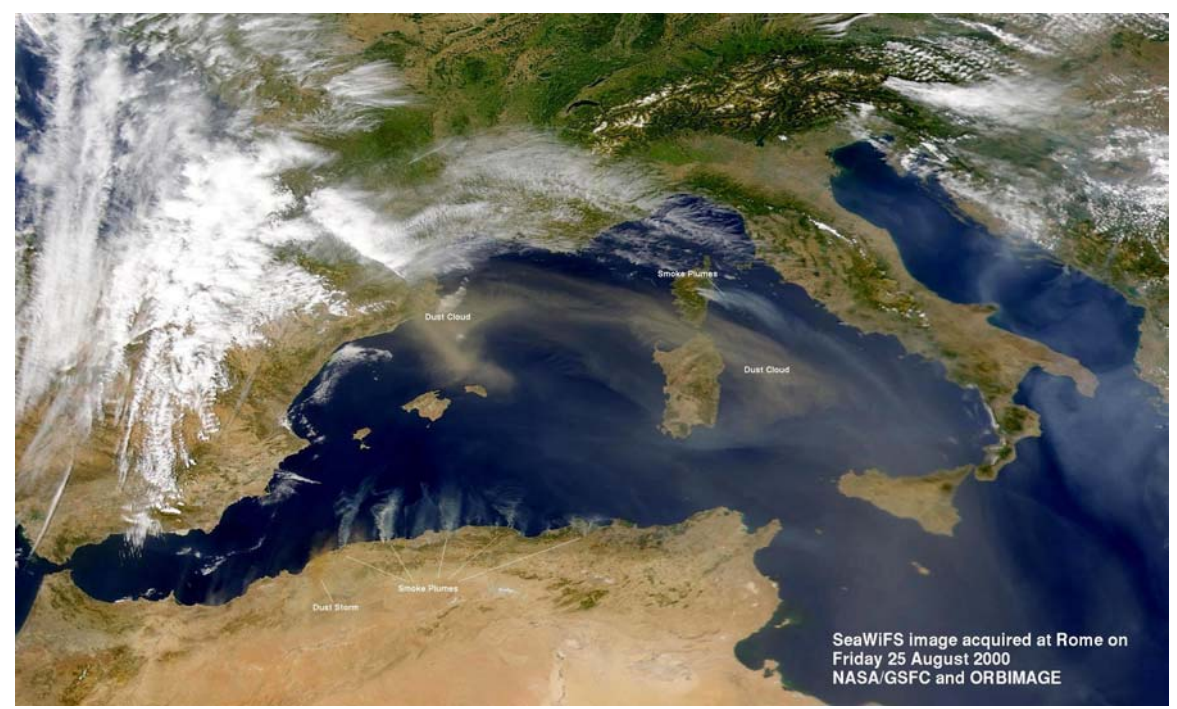

Fig. 3. SeaWiFS image of the Mediterranean Area on 25 August 2000.

$(0.3 \mu \mathrm{m}<\mathrm{d}<0.5 \mu \mathrm{m})$ (Fig. 2). During the first days, this concentration experienced large diurnal cycles with maxima around midnight. As mentioned earlier, the concentrations did not followed the increase in $\mathrm{PM}_{10}$ concentrations dur- ing the stronger part of the dust episode. Instead, the most striking feature was a large increase in concentration (also seen for the particles in the $0.5 \mu \mathrm{m}>\mathrm{d}>1 \mu \mathrm{m}$ channel) starting during the dust episode, reaching a maximum in the early 
NOAA HYSPLIT MODEL Backward trajectories ending at 12 UTC 26 Aug 00 FNL Meteorological Data

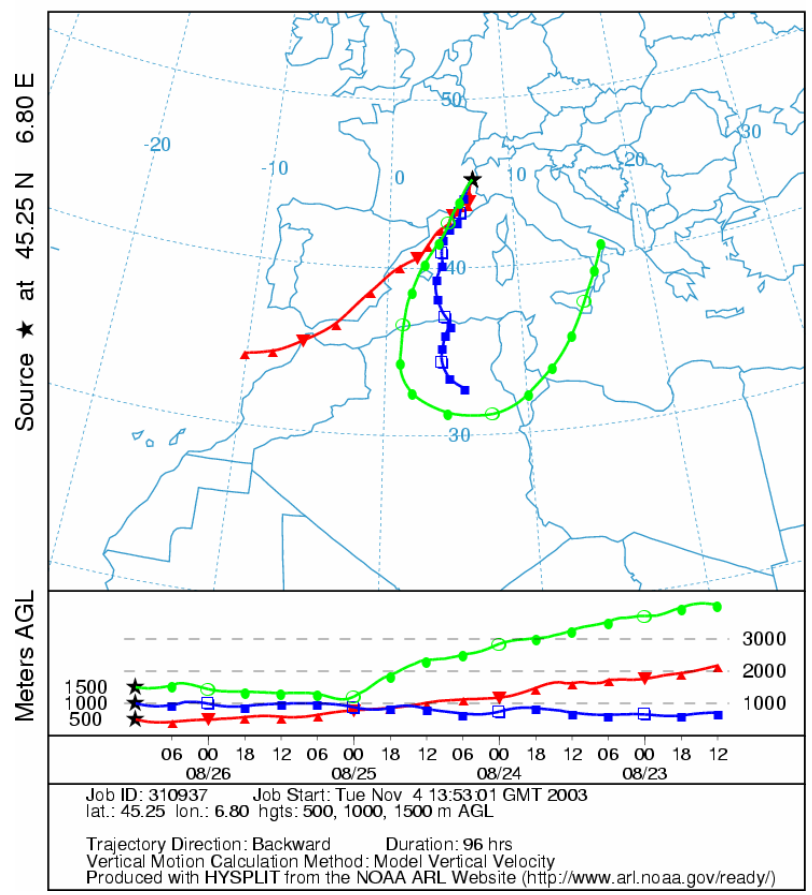

Fig. 4. Airmass back trajectories ending in Sollières on 26 August 2000 .

hours of 27 August, and lasting till noon on 27 August concurrently with the end of south winds at ground. It is likely that this episode of large concentrations of submicron particles was associated with an air mass influenced by anthropogenic emissions from outside of the valley, i.e. from northern Italy (Colomb et al., 2002). Despite the large increase in submicron particles, the particle mass was not influenced much, as seen with the $\mathrm{PM}_{10}$ series. The next sections will discuss of the evolution of some chemical concentrations in parallel with these changes in mass and particle numbers, particularly during this dust episode.

\subsection{Evolution of concentrations for primary components}

Figure 5 presents the evolution of concentrations of soluble calcium, in parallel with changes in particle number concentrations in the upper size range. Soluble calcium is generally considered as a good surrogate for the occurrence of crustal species in the aerosol, despite other sources (sea salts, combustion processes). During the first part of the week, there was no strong correlation between $\mathrm{PM}_{10}$ and calcium variations $\left(r^{2}=0.61 ; n=42\right)$, indicating that the evolutions of the aerosol mass are not totally driven by changes in the crustal component. However, the covariations increased between the concentrations of calcium, large particles, and $\mathrm{PM}_{10}$ during the overall $\mathrm{PM}_{10}$ increase. Mean $\mathrm{Ca}^{2+}$ concentrations during
Table 1. Arithmetic mean concentrations and standard deviation before $(n=26)$ and during $(n=4)$ the dust event. All concentrations in $\mu \mathrm{g} \mathrm{m}^{-3}$.

\begin{tabular}{lcc}
\hline & Dusty period & Before dusty period \\
\hline $\mathrm{PM}_{10}$ & $146 \pm 66$ & $23 \pm 11$ \\
$\mathrm{OC}$ & $7.46 \pm 2.36$ & $3.40 \pm 1.23$ \\
$\mathrm{EC}$ & $0.37 \pm 0.19$ & $0.37 \pm 0.18$ \\
$\mathrm{Ca}^{2+}$ & $4.80 \pm 1.98$ & $0.63 \pm 0.49$ \\
$\mathrm{Na}^{+}$ & $0.31 \pm 0.48$ & $0.11 \pm 0.07$ \\
$\mathrm{~K}^{+}$ & $0.28 \pm 0.24$ & $0.06 \pm 0.05$ \\
$\mathrm{Mg}^{2+}$ & $0.08 \pm 0.02$ & $0.03 \pm 0.01$ \\
$\mathrm{Cl}^{-}$ & $0.90 \pm 1.62$ & $0.13 \pm 0.13$ \\
$\mathrm{NO}_{3}^{-}$ & $1.05 \pm 0.42$ & $0.39 \pm 0.11$ \\
$\mathrm{SO}_{4}^{2-}$ & $2.57 \pm 0.87$ & $1.09 \pm 0.32$ \\
Formate & $0.057 \pm 0.017$ & $0.033 \pm 0.011$ \\
Glutarate & $0.010 \pm 0.008$ & $0.009 \pm 0.004$ \\
Oxalate & $0.186 \pm 0.088$ & $0.074 \pm 0.034$ \\
\hline
\end{tabular}

this period reached $4.80 \pm 1.98 \mu \mathrm{g} \mathrm{m}^{-3}(\mathrm{n}=4)$, a very large increase compared to the previous days $\left(0.63 \pm 0.49 \mu \mathrm{g} \mathrm{m}^{-3}\right.$, $\mathrm{n}=26$ ). These very large calcium concentrations are again in agreement with the hypothesis of a desert dust plume reaching the sampling site at that time. Soluble calcium represented $3.4 \pm 0.7 \%$ of the $\mathrm{PM}_{10}$ mass during the dust period, which is also consistent with a Saharan origin (Loÿe-Pilot et al., 1986). The mean $\mathrm{Ca}^{2+}$ contribution to $\mathrm{PM}_{10}$ mass during the other parts of the week was slightly lower, with a value of $2.5 \pm 1.4 \%$.

Figure 5 also presents the evolution of concentrations of $\mathrm{Na}^{+}, \mathrm{Cl}^{-}$, and $\mathrm{K}^{+}$for the whole sampling week. Concentrations are presented in Table 1, comparing average concentrations before the dust episode and those during the $\mathrm{PM}_{10}$ event. Concentrations of $\mathrm{Na}^{+}$and $\mathrm{Cl}^{-}$were really low during the first days of campaign (at about $110 \mathrm{ng} \mathrm{m}^{-3}$ on average), in agreement with a low impact of marine air masses during anticyclonic situations in the area. However, concentrations of both species experienced a peak matching exactly the initial increase in large particle numbers. Soluble $\mathrm{K}^{+}$ also followed the same behaviour, while $\mathrm{Mg}^{2+}$ concentrations (not shown) were not changing much at that time. The large enrichment in $\mathrm{Na}^{+}$may be an indication of marine influences. However, no methanesulfonic acid (MSA) was detected in parallel which could confirm a direct marine influence. The large deficit in $\mathrm{Mg}^{2+}$ compared to the sea salt chemical profile is also against such a direct marine origin (the concentrations of $\mathrm{ssMg}^{2+}$ should be about $140 \mathrm{ng} \mathrm{m}^{-3}$ based on a marine mass ratio $\mathrm{Mg}^{2+} / \mathrm{Na}^{+}=0.12$, with a concentration measured at $77 \mathrm{ng} \mathrm{m}^{-3}$ only). Another hypothesis is that the enrichments in $\mathrm{Na}^{+}$and $\mathrm{Cl}^{-}$were linked with a dust source containing halite, as seen in a previous dust episodes over the Alps (Schwikowski et al., 1995) or the 

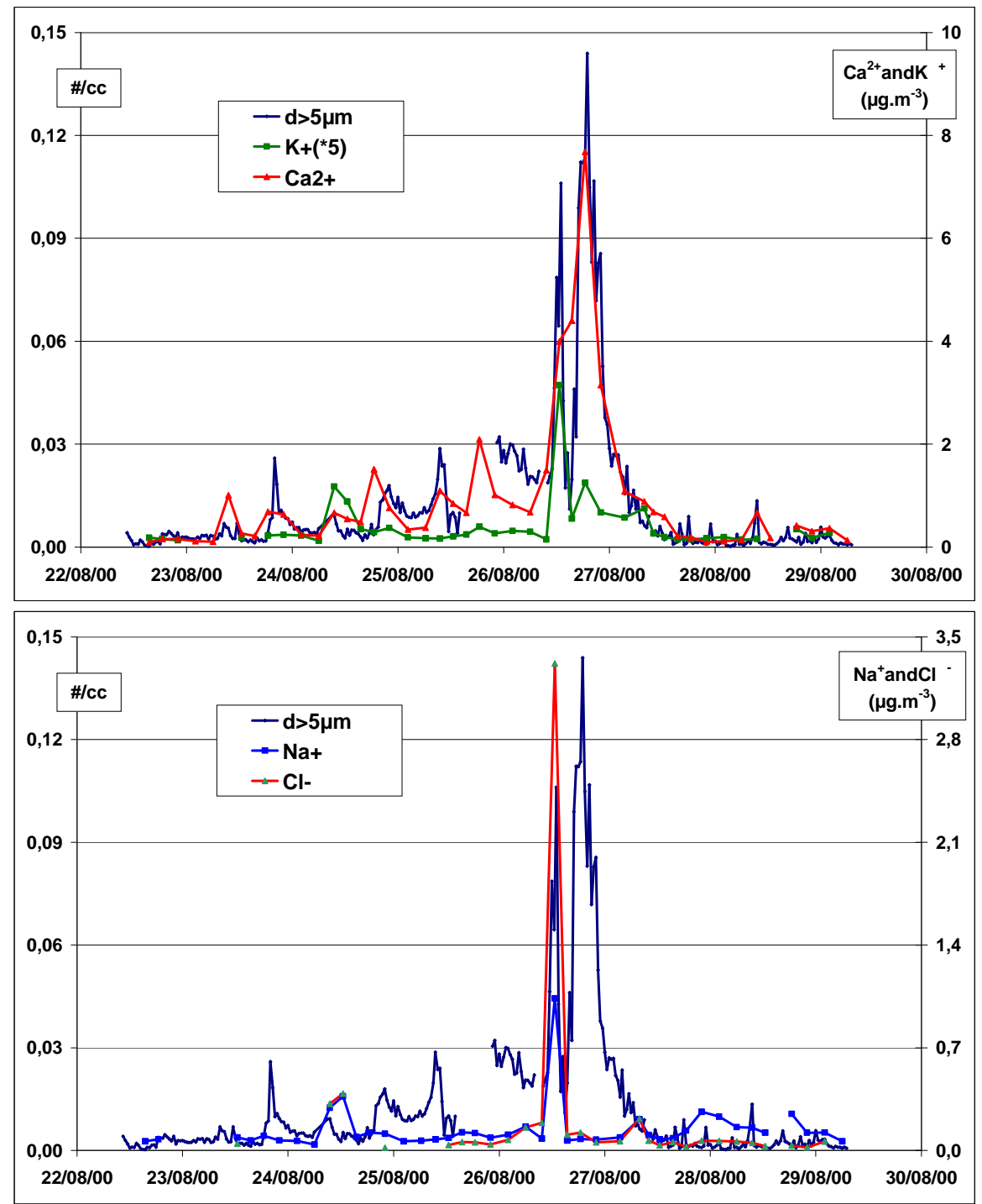

Fig. 5. Evolution of large particle number concentrations during the sampling week, together with changes in concentrations of some cations.

Atlantic (Formenti et al., 2003). Such sources are generally rather depleted in $\mathrm{Mg}^{2+}$. However, the ratios $\mathrm{Ca}^{2+} / \mathrm{Na}^{+}$and $\mathrm{K}^{+} / \mathrm{Na}^{+}$were much larger than those in halite (and also than those in seawater), an indication that the aerosol was most probably characterized by a mixture of material from two distinct sources, a calcium-containing mineral mixed with halite.

Further, the mass ratios $\mathrm{Cl}^{-} / \mathrm{Na}^{+}$(at 3.20) was also much larger than the halite (1.5) and sea water (1.75) ratios, while aging processes generally lead to $\mathrm{Cl}^{-}$depletion during seasalt transport (Zhuang et al., 1999 and references therein). This enrichment in $\mathrm{Cl}^{-}$could be due to a mixing of large particles with biomass burning emissions that would also enhance $\mathrm{K}^{+}$concentrations (Echalar et al., 1995). Biomass burning plumes are visible on the Algerian coastline on the SeaWiFS picture (cf. Fig. 3). However, this hypothesis is not substantiated by the data, with the lack of increase of the fine particles number concentrations (cf. Fig. 2) or (discussed below) that of elemental carbon and of specific carboxylic acids (including oxalate) generally associated with this type of emissions (Seinfeld and Pandis, 1998). $\mathrm{Cl}^{-}$enrichments compared to seawater have already been reported for crustal aerosol (Zhang and Iwasaka, 2001), and attributed to the deposition on dust particles of chlorine-containing gases. This mechanism is a hypothesis to explain the $\mathrm{Cl}^{-}$enrichment observed during the first part of the dust episode. However, for some reasons, this process did not take place in the purely crustal part of the episode.

Overall, the observation of primary species on a short time scale during this dust event shows that aerosol contained a mixture of different mineral dusts, clearly changing in a time frame of about $12 \mathrm{~h}$. The large drop in the particle number 


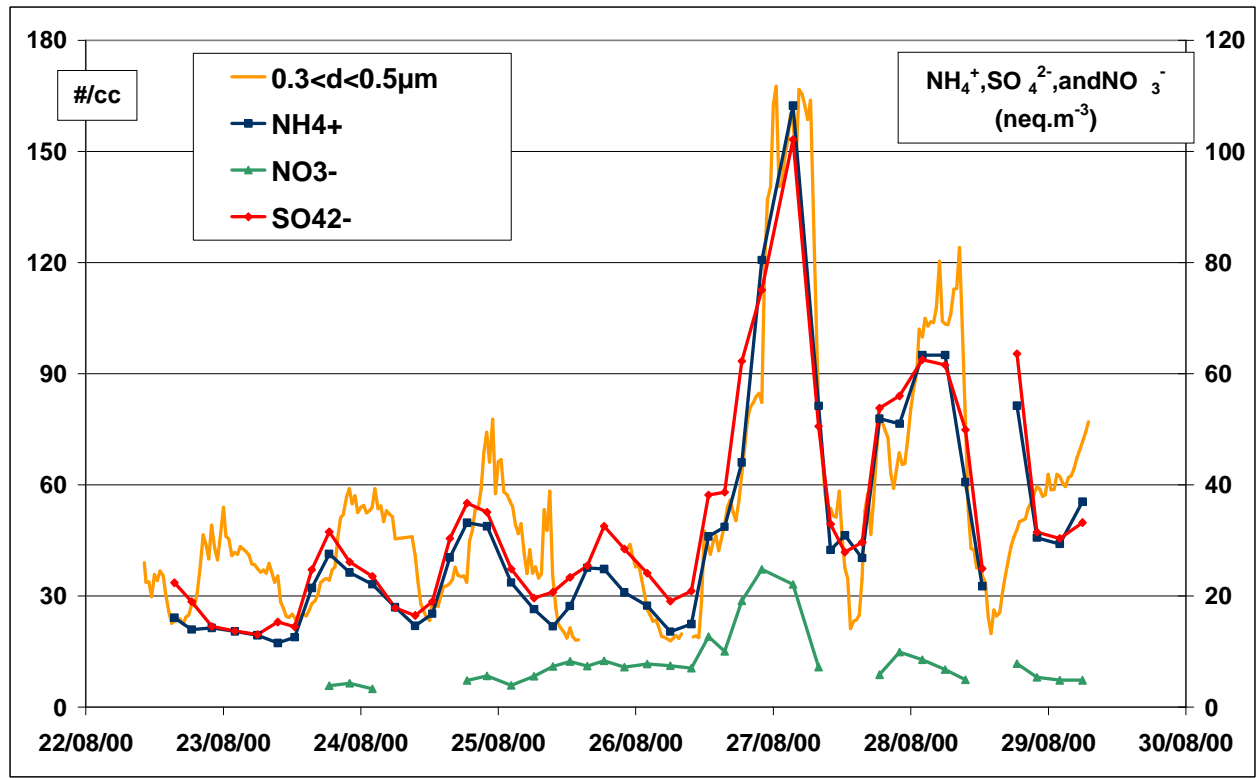

Fig. 6. Evolution of submicron particle number concentrations during the sampling week, together with changes in concentrations of some anions.

concentrations and $\mathrm{PM}_{10}$ in the middle of the episode was associated with a radical change in chemistry. Our data do not allow further examination of the reasons of this change. As a general consequence, one can say that interpretations of observations of Saharan dust over Europe based on the bulk chemistry of integrated samples (24-h aerosol sampling or dust horizons in ice core records) can be biased if such potential evolutions are not considered. This would be the case, for example, for the possible uptake of chlorine-containing gases during transport, which is totally different between the first and second parts of this episode.

3.3 Evolution of concentration for secondary inorganic components

Many studies pointed out to the large potential of interactions between alkaline dust particles and gases from anthropogenic origin (mainly for $\mathrm{NO}_{\mathrm{y}}$ and $\mathrm{SO}_{\mathrm{x}}$ species). Such interactions were demonstrated in several field experiments totally or partly dedicated to studies of dust aerosol. Examples include GTE/ABLE 1 (Talbot et al., 1986), ACE-2 (Putaud et al., 2000), IDAF (Galy-Lacaux et al., 2001), MINATROC (for nitrate) (Putaud et al., 2003), TRACE-P (Jordan et al., 2003), SHADE (Formenti et al., 2003). Other measurements also showed sulfate and nitrate enhancements on dust aerosol, at the Puy de Dome (France) (Sellegri et al., 2003), in the Barbados (Savoie et al., 1989) or in East Asia (Mori et al., 2003; Song and Carmichael, 2001). It is generally pointed out that $\mathrm{HNO}_{3}$ and $\mathrm{SO}_{2}$ uptakes are probably limited by the availability of acidic gases, rather than dust concentrations (Jordan et al., 2003). However, some other measurements showed no enhancement of these species during dust episodes, like for example in LBA-CLAIRE (Formenti et al., 2001), MINATROC (for sulfate)(Putaud et al., 2003), or at the Jungfraujoch (Schikowski et al., 1995).

Very recently, the uptake of $\mathrm{HNO}_{3}, \mathrm{~N}_{2} \mathrm{O}_{5}, \mathrm{NO}_{2}$ and $\mathrm{SO}_{2}$ was investigated in the laboratory on real mineral dust surfaces and proxies like aluminium oxide (see Usher et al., 2003 for a review). The uptake of $\mathrm{HNO}_{3}$ is irreversible i.e. dust may act as a total sink for $\mathrm{HNO}_{3}$. However, this sink is limited by the fact that the surface of dust gets pacified quite rapidly, on a time scale dependent on relative humidity. Nevertheless, the uptake of $\mathrm{HNO}_{3}$ on mineral dust should be considered as an important sink for $\mathrm{NO}_{\mathrm{y}}$ in those parts of the atmosphere that are influenced by dust emissions (Boerensen et al., 2000; Hanisch and Crowley, 2001a, b, 2003a, b; Kirchner et al., 1999; Ullerstam et al., 2002).

Other gases are also taken up by dust. For example, $\mathrm{N}_{2} \mathrm{O}_{5}$ interacts with dust with an uptake coefficient about an order of magnitude lower than $\mathrm{HNO}_{3}$. This rate of uptake is also highly affected by humidity. While for $\mathrm{HNO}_{3}$ and $\mathrm{N}_{2} \mathrm{O}_{5}$ the uptake on dust may be significant, the interactions of $\mathrm{NO}_{2}$ with dust are occurring on much longer timescale and therefore present limited atmospheric implications (Usher et al., 2003). Formation of sulfate on dust particles was also observed, due to the surface oxidation of $\mathrm{SO}_{2}$ by $\mathrm{O}_{3}$ through a two-step mechanism that involves physisorption of $\mathrm{SO}_{2}$ followed by its oxidation. The associated uptake coefficient is in the order of $10^{-3}$ to $10^{-7}$, depending on the ozone concentration. The uptake coefficient for ozone lies in the range from $10^{-2}$ to $10^{-8}$. Again, in this system, a strong influence of water vapour was observed (Ullerstam et al., 2002). 
These processes have been included in GCM's to evaluate the global impact of interactions between $\mathrm{NO}_{\mathrm{y}}, \mathrm{SO}_{\mathrm{x}}$, and dust aerosol (Dentener et al., 1996; Liao et al., 2003). It showed that, over large regions of the Northern Hemisphere and particularly close to source regions of mineral dust, sulfate and nitrate can be associated with the coarse mode of the aerosol in proportions up to $50 \%$. These quantifications remain uncertain, due to the lack of precise field and laboratory studies of some of the parameters involved (Liao et al., 2003).

Figure 6 presents the evolution of the concentrations of $\mathrm{SO}_{4}^{2-}, \mathrm{NH}_{4}^{+}$, and $\mathrm{NO}_{3}^{-}$(expressed in $\mathrm{nEq} \mathrm{m}^{-3}$ ) during the whole week, together with the number concentrations of the smaller particles. Sulfate concentrations followed a diurnal cycle during the days preceding the dust episode, with maxima during late afternoon or early evening, following a different pattern than the submicron particle number concentrations. On the contrary, sulfate and submicron particles totally tracked each other during the end of the period, starting during the dust episode. The very high concentrations reached compared to the background earlier in the week are in favor of an origin from outside of the valley for this anthropogenic episode, an hypothesis also substantiated by the wind direction still coming from the south at that time. A very good correlation existed between $\mathrm{NH}_{4}^{+}$and $\mathrm{SO}_{4}^{2-}$ concentrations for the whole week (slope $=1.04 ; r^{2}=0.93 ; n=46$; concentrations in $\mathrm{nEq} \mathrm{m}^{-3}$ ), including during the dust episode. The ratio of sulfate concentration to submicron particle number $(0.3 \mu \mathrm{m}<\mathrm{d}<1 \mu \mathrm{m})$ (not shown) is not drastically changing during the whole week, at $0.30 \pm 0.1010^{-6} \mu \mathrm{gSO}_{4}^{2-} / \mathrm{part}$, with no obvious deviation during the dust episode. All of these information point out to sulfate being mainly in the form of $\left(\mathrm{NH}_{4}\right)_{2} \mathrm{SO}_{4}$ in submicron particles for the whole period, including the dust event. An upper limit for the concentration of sulfate in the supermicron size range (using $2 \sigma$ of the ratio of sulfate concentration to submicron particle number) can be set at about $1.7 \mu \mathrm{g} \mathrm{m}^{-3}$ on average over the dust episode, with the hypothesis of a stable ratio of sulfate concentration to submicron particle number. It translates into a maximum mass ratio of $\mathrm{SO}_{4}^{2-} / \mathrm{Ca}^{2+}$ at 0.36 for supermicron particle, which is lower than most values presented in other studies showing low interactions between dust and $\mathrm{SO}_{\mathrm{x}}$ (Formenti et al., 2001; Putaud et al., 2003; Schikowski et al., 1995; Sellegri et al., 2003). Further, sulfate in the supermicron size range originates both from initial gypsum $\left(\mathrm{CaSO}_{4}\right)$ in the crustal material (which has a low content in the northern part of Northern Africa; Claquin et al., 1999) and from interactions between mineral dust (mainly calcite, $\mathrm{CaCO}_{3}$ ) and $\mathrm{SO}_{\mathrm{x}}$. It is therefore likely that the true concentration of non-crustal sulfate (i.e. coming from interaction of $\mathrm{SO}_{\mathrm{x}}$ with mineral dust) was lower than $1.7 \mu \mathrm{g} \mathrm{m}^{-3}$ in our case. Therefore, our data set indicates very weak interactions between crustal particles and $\mathrm{SO}_{\mathrm{x}}$ during transport.
Nitrate concentrations (cf. Fig. 6) were rather low during the first part of the week, with many samples below the detection limit at $0.29 \mu \mathrm{g} \mathrm{m}^{-3}$. Neither obvious temporal patterns nor links with particle size can be inferred from the data during this period. A marked increase in nitrate concentrations took place on midday on 26 August, coincident with the onset of the dust episode. It doubled the average concentration of the previous days, up to $1.05 \pm 0.42 \mu \mathrm{g} \mathrm{m}^{-3}$ during the dust episode. There was however no strong link between the evolutions of nitrate concentrations and particle numbers in any size during 26 and 27 August. The maximum in nitrate concentration clearly did not follow that of sulfate, but was in between the maxima in particle number for the lower and upper size ranges. Preliminary investigations show that the best relation is found between nitrate concentrations and total particle surface (Fig. 7), considering reasonable hypotheses for the average diameters in each 4 size ranges. It is therefore difficult to tell if nitrate was preferentially linked to the dust particles or to the submicron particles advected during the anthropogenic episode, a most likely situation being probably in between. It follows that the equivalent ratio $\mathrm{NO}_{3}^{-} / \mathrm{Ca}^{2+}$ observed during the dust period, at $0.16 \pm 0.11$, represents the upper limit for that in the coarse particle range. This ratio is much lower than that measured in many other studies (Song and Carmichael, 2001; GalyLacaux et al., 2001; Formenti et al., 2003; Mori et al., 2003).

Finally, all of these characteristics, including concentrations, size distributions, and mass ratio $\mathrm{SO}_{4}^{2-} / \mathrm{Ca}^{2+}$ and $\mathrm{NO}_{3}^{-} / \mathrm{Ca}^{2+}$ show that interactions of anthropogenic species $\mathrm{NO}_{\mathrm{y}}$ and $\mathrm{SO}_{\mathrm{x}}$ with mineral dust were very limited in our case, as opposed to observations from many other field studies. It is therefore interesting to figure out if these concentrations are compatible with the current knowledge of the mechanisms involved in the interactions.

Below, we try to compare the concentrations measured for sulfate and nitrate with first approach calculations where the particulate ions are assumed to be produced solely by the uptake of precursor gases. We consider a simple case where the air mass is isolated from the surroundings (i.e. there is no exchanges and replenishments of gases with other air masses). For this purpose, we will consider the following simple unbalanced reactions:

$$
\begin{aligned}
& \mathrm{HNO}_{3}+\text { Dust } \rightarrow \mathrm{NO}_{3}^{-}+\text {Dust } \\
& \mathrm{N}_{2} \mathrm{O}_{5}+\text { Dust } \rightarrow 2 \mathrm{NO}_{3}^{-}+\text {Dust } \\
& \mathrm{SO}_{2}+\mathrm{O}_{3}+\text { Dust } \rightarrow \mathrm{SO}_{4}^{-}+\text {Dust }
\end{aligned}
$$

The loss rate from the gas phase is assumed to follow first order kinetics. Therefore, the evolution of the concentration of a gaseous precursor can be expressed as:

$$
[G] t=[G]_{0} \exp (-k t)
$$

where $[G] t$ is the gas phase concentration of the precursors (i.e. $\mathrm{HNO}_{3}, \mathrm{~N}_{2} \mathrm{O}_{5}, \ldots$ ) at time $t$ (where time is referring to 


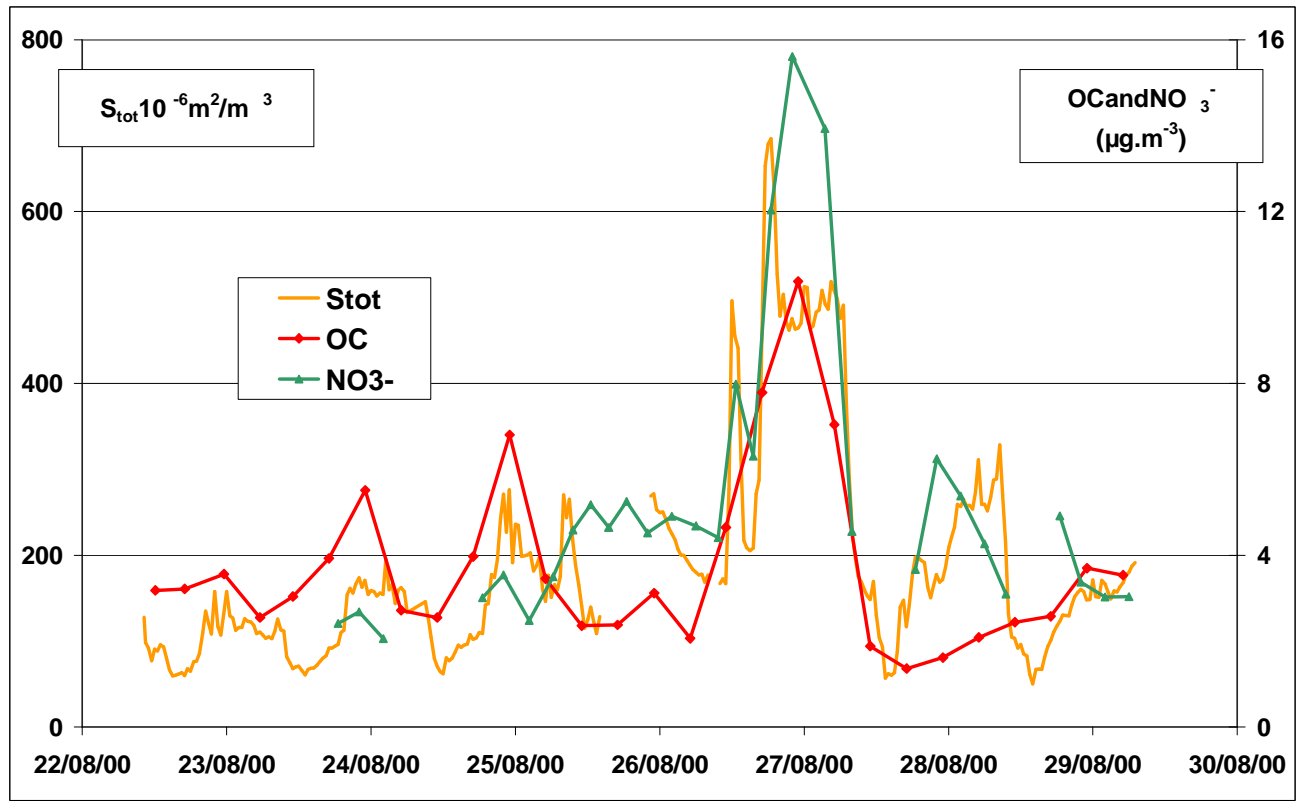

Fig. 7. Evolution of particle total surface area during the sampling week, together with changes in concentrations of nitrate and OC.

the transport time), $[G] 0$ is the initial concentration in the air mass, and $k$ is the first order rate constant at which the gaseous precursor is taken up by dust. This rate constant can then be written as:

$k=\frac{1}{4}<c>\gamma S_{\text {dust }}$

with $\langle c\rangle$ the molecular speed of the gas, $\gamma$ the uptake coefficient, and $S_{\text {dust }}$ the surface concentration of dust (in $\mathrm{m}^{2} / \mathrm{m}^{3}$ ). In these crude calculations, the uptake coefficient is assumed to be the reactive uptake coefficient without any considerations of diffusion limitation (which is anyhow small in the present situation). All input parameters are listed in Table 2. Initial gas phase concentrations are estimated for the area in northern Algeria where the dust may originate, concentration of $\mathrm{SO}_{2}$ is estimated from Chin and Jacob (1996), while concentrations for $\mathrm{NO}_{\mathrm{x}}$ and $\mathrm{NO}_{\mathrm{y}}$ are calculated online with Geos Chem (http://www.atmos. washington.edu/ jaegle/geoso3_start.html). These concentrations are compatible with measurements obtained during a Saharan dust episode observed in Italy during MINATROC (Hanke et al., 2003). We can consider a transit time of about 3-5 days, compatible with back trajectories (cf. Fig. 4) and a compilation of events observed at the Jungfraujoch (Collaud Coen et al., 2003).

The results of this very simple calculation are depicted in Fig. 8. The first issue is that sulfate is produced at a much slower rate than nitrate. The latter is formed very rapidly within the first minutes following the uplifting of the air mass. The rates of formation are then slowed down for both species, as the air mass gets depleted in the gaseous precursors. The simulated concentrations are roughly consistent
Table 2. Initial parameters used for the simulation of nitrate and sulphate on dust particles, using a very simple approach based on first order kinetics in the case of an isolated air mass.

\begin{tabular}{lrll}
\hline Initial parameters & Initial values & Units & Uptake coefficients $\left(^{*}\right)$ \\
\hline $\mathrm{NO}_{2}$ & 2.0 & $\mathrm{ppb}$ & $10^{-4}$ \\
$\mathrm{HNO}_{3}$ & 1.0 & $\mathrm{ppb}$ & 0.1 \\
$\mathrm{~N}_{2} \mathrm{O}_{5}$ & 10.0 & $\mathrm{ppt}$ & $10^{-3}$ \\
$\mathrm{O}_{3}$ & 50.0 & $\mathrm{ppb}$ & \\
$\mathrm{SO}_{2}$ & 500.0 & $\mathrm{ppt}$ & $10^{-3}$ \\
& & & \\
Temperature & 298.0 & $\mathrm{~K}$ & \\
Pressure & 0.5 & $\mathrm{~atm}$ & \\
Radius & 0.5 & $\mu \mathrm{m}$ & \\
Density & 3000.0 & $\mathrm{~m} 2 / \mathrm{kg}$ & \\
Mass concentration & 100.0 & $\mu \mathrm{g} / \mathrm{m}^{3}$ & \\
Surface concentration & $3.010^{-4}$ & $\mathrm{~m}^{2} / \mathrm{m}^{3}$ & \\
\hline
\end{tabular}

(*) These values are approximates ones based on real experimental values. This step is needed as these uptake coefficients are depended on many parameters which are not accounted for in our simplified calculations.

with our observations for sulfate, but are too high (probably by a factor of 2-5) for nitrate. However, it shows that this very simplified calculation can capture some insights of the formation of nitrate and sulfate as observed during the POVA campaign in 2000.

Figure 8 presents a second set of calculations that can be considered as a lower limit, with the uptake coefficients 


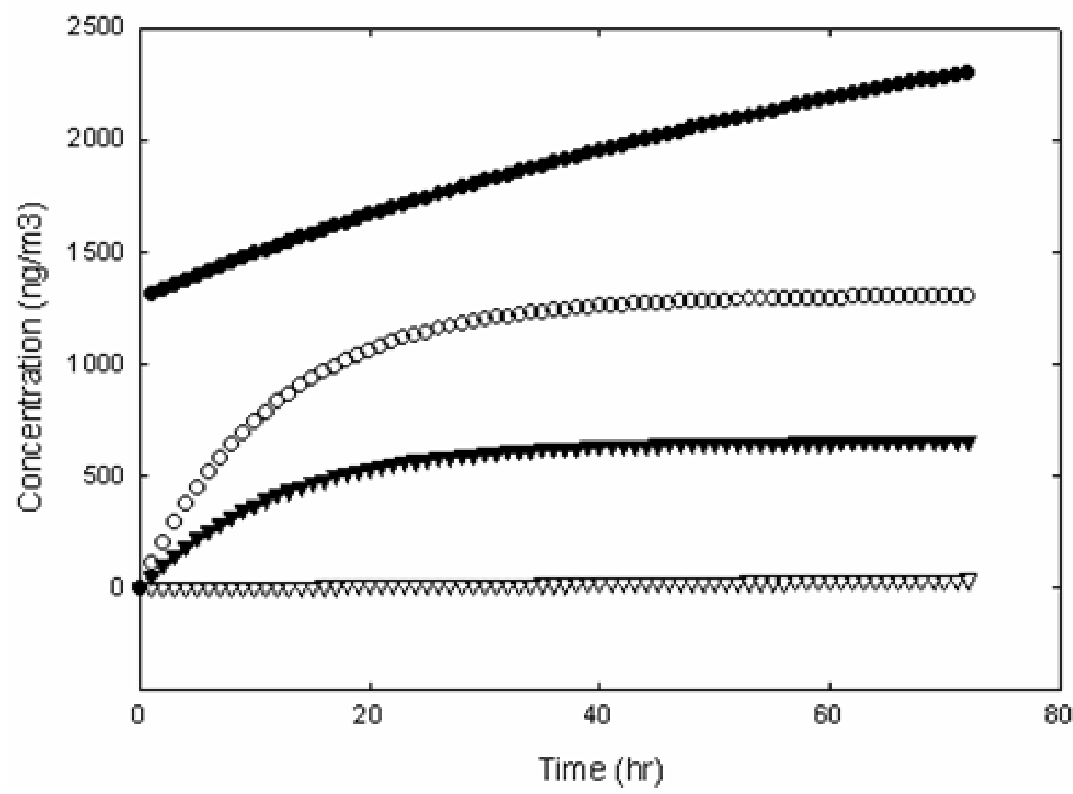

Fig. 8. Time evolution of the simulated concentrations of nitrate and sulphate on dust particle using a very simple approach based on first order kinetics and for an isolated air mass (see text). Triangle: sulphate; circle: nitrate; closed symbols: best guess simulation; open symbols: lower limit (see text for details). Nitrate in the best guess case starts at 0 and increases up to $1300 \mathrm{ng} \mathrm{m}^{-3}$ in the first few minutes.

divided by 100 . Uptake coefficients are directly linked to the mass flux of trace gases being trapped by the dust particles. However, during this process the surface of the particle is changing as the number of potential reaction and/or adsorption sites is decreasing. Laboratory studies have shown that the interactions of nitrogen oxides with dust are quite fast at small contact times but that the chemical conversion is slowing down with time. These studies have also shown that humidity has a crucial role in the regeneration of the surface properties. In fact, at very low humidity the surface of a dust particle might become totally passivated. As a consequence, a totally dry air mass might show quite different behaviour in terms of $\mathrm{SO}_{\mathrm{x}}$ and $\mathrm{NO}_{\mathrm{y}}$ interactions with dust. The lower limit cases in Fig. 8 tentatively represent these conditions of low reaction. As expected, the levels of nitrate and sulfate are decreased compared to the base case discussed above, with concentrations of sulfate approaching zero. Conversely, concentrations of nitrate are still in the upper limit of the concentrations measured in the field.

Owing very large uncertainties in many inputs parameters for these estimations, there is no strong contradiction in the comparisons between the field data and these very crude estimations of sulfate and nitrate associated to dust. Therefore, the calculations most probably indicate that the low concentrations measured in our case can only result from conditions were the dust-loaded air mass sampled did not mixed at any time with polluted air mass during its transport or that the transport occurred under very dry conditions leading to some strong surface passivation of the dust.
3.4 Evolution of the concentrations of the carbonaceous fraction

Very few data exist on measurements of OC and EC during Saharan dust episodes, or more generally on mineral aerosol. Formenti et al. (2003) did not detected OC on atmospheric samples during a Saharan dust outbreak over the Atlantic during the SHADE experiment. Putaud et al. (2000) presented data showing OC concentrations increasing by a factor of 3 over the regional background during a mineral dust episode observed during ACE-2, but indicated that this episode is probably mixed with an anthropogenic air mass. So far, only Chuang et al. (2003) proposed observations during ACE-Asia, showing coagulation of EC during long range transport of mineral dust mixed with air mass impacted by anthropogenic emissions. No OC measurements during typical mineral dust episodes are currently reported so far for ACE-ASIA, directly showing interactions of OC with dust particles. In the same way, laboratory studies on the topic are still scant (see Usher et al., 2003 for a review). Some evidences of adsorption of organic vapors on mineral dust are presented, for example by Goss and Eisenreich (1996) and Li et al. (2001).

The evolutions of the concentrations of EC and OC during our field study are presented on Fig. 9, together with the evolutions of the particle number concentrations in the smaller and larger channels. During the first part of the week, OC concentrations varied between 2.4 and $7.8 \mu \mathrm{gC} \mathrm{m}^{-3}$, following a strong diurnal cycle with night time maxima close to 


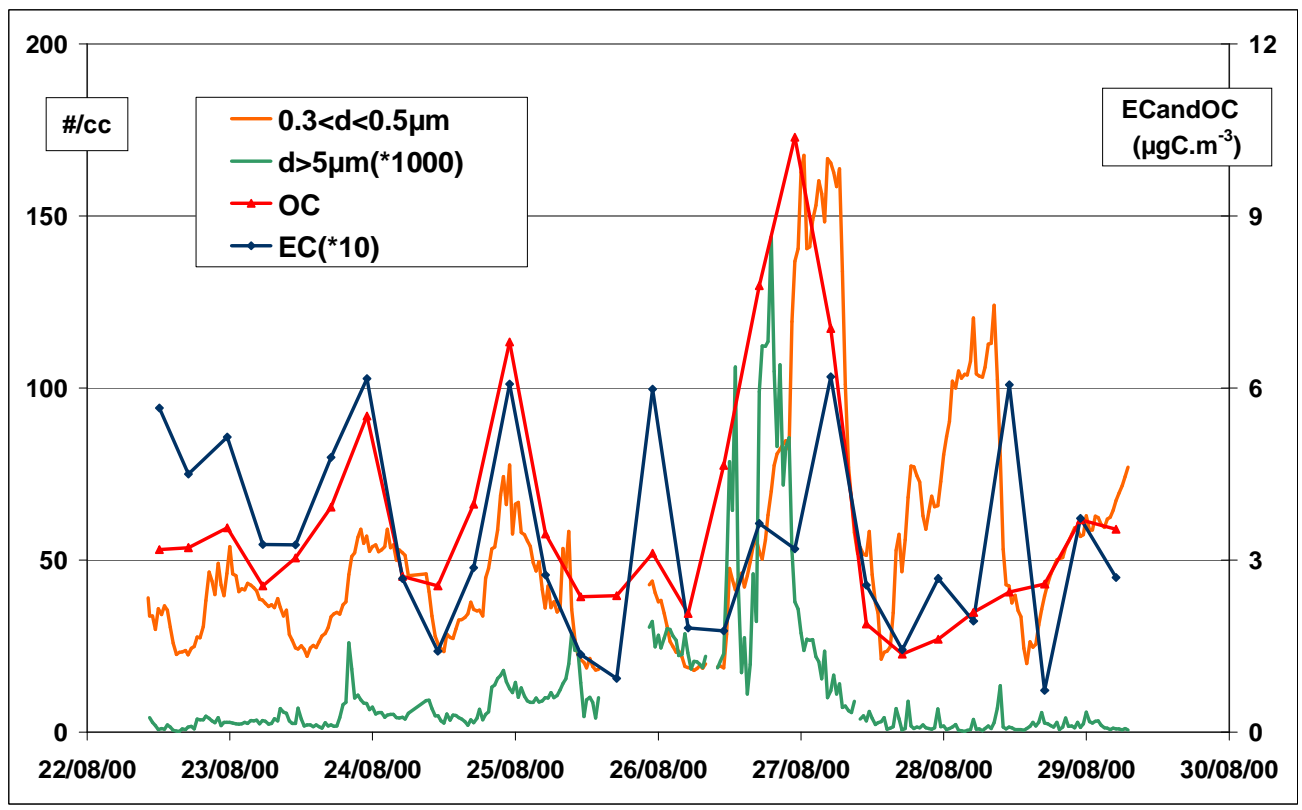

Fig. 9. Evolutions of OC and EC concentrations during the sampling week, together with changes in particle number concentrations in the upper and lower channels.

that of the submicron particles number. The series show and increase of OC concentrations starting in the morning of 26 August, together with that of the super-micron particle number. Sub-micron particle number also increased at the same time, and it is therefore difficult to show clear evidence that a fraction of OC was associated with dust particles. However, OC concentrations reach their maximum simultaneously to nitrate, i.e. before the sulfate and sub micron particles maxima, while EC maximum concentration lagged that of $\mathrm{OC}$, following that of sulfate. Further, like for nitrate, the maximum in OC concentrations was clearly associated with a first approximation of the total surface area of the aerosol during 26 and 27 August (Fig. 7). All of this information point out, like for nitrate, to some extent of OC associated with mineral dust. It should be mentioned that a fraction of this increase could be from carbon from the carbonate fraction that was not clearly resolved during TOT analysis. However, in spite of the absolute increase of OC concentrations during this period, the contribution of $\mathrm{OC}$ to $\mathrm{PM}_{10}$ levels largely decreased, being half of that during the rest of the sampling period $\left(\mathrm{OC} / \mathrm{PM}_{10}=9.2 \%\right.$ and $18.2 \%$ during and before the dust event, respectively).

EC concentrations do not show a clear trend during the dust period (Fig. 9), with low concentrations and weak contributions to $\mathrm{PM}_{10}$ mass. It corroborates the hypothesis that the dust cloud was not mixed with a polluted air mass during its transport.

As OC is a mixture of hundreds of individual compounds spanning a wide range of chemical and thermodynamic properties, interaction between mineral dust and organic com- pounds depends of the amount and properties of each compound. Some carboxylic acids were measured with ionic chromatography (thus on a different time scale than OC, cf. Sect. 2.2.) with, according to decreasing weekly average concentrations, oxalate $\left(93.7 \pm 52.8 \mathrm{ng} \mathrm{m}^{-3}\right)$, formate $\left(35.4 \pm 13.8 \mathrm{ng} \mathrm{m}^{-3}\right)$, succinate $\left(21.5 \pm 9.6 \mathrm{ng} \mathrm{m}^{-3}\right)$, malate $\left(18.1 \pm 8.6 \mathrm{ng} \mathrm{m}^{-3}\right)$, malonate $\left(15.9 \pm 10.6 \mathrm{ng} \mathrm{m}^{-3}\right)$, glutarate $\left(9.6 \pm 5.5 \mathrm{ng} \mathrm{m}^{-3}\right)$, and glyoxylate $\left(5.5 \pm 3.8 \mathrm{ng} \mathrm{m}^{-3}\right)$. Altogether, these acids represented $5.4 \%$ of OC by mass on a weekly average (hence a lower proportion of particulate organic matter).

Figure 10 presents the evolution of the concentrations of formate, glutarate, and oxalate for the whole week, together with the total surface area of the aerosol. Glyoxylate, succinate, malonate, and malate (all not shown) behaved very much like glutarate. During the first part of the week, oxalate and glutarate followed a strong diurnal cycle totally linked to that of OC. The evolution of formate was quite different, with no regular diurnal cycle. However, Fig. 10 shows a different behavior for the 3 acids on 26 and 27 August. Formate concentrations followed closely the evolution of the total aerosol surface. Glutarate concentrations were closely related with that of sulfate and with the number of submicron particles. Conversely, the evolution of oxalate concentrations was in between that of the two other acids, and was very much related to that of $\mathrm{OC}$.

To the best of our knowledge, there is no previous publication presenting concentrations of individual organic species on particulate dust, except for Collaud Coen et al. (2003) who underline an enhancement of formate and acetate 


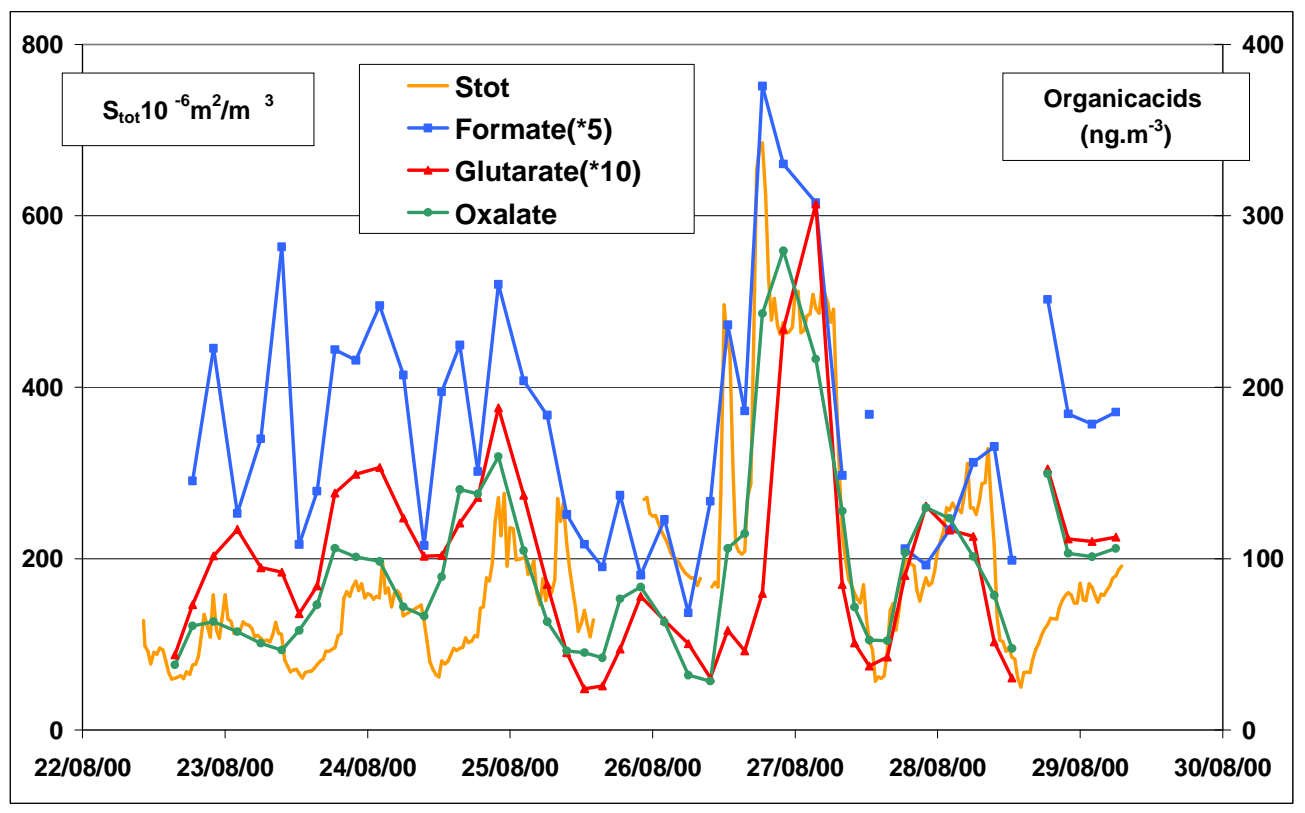

Fig. 10. Evolutions of concentrations of some organic acids during the sampling week, together with changes in total particle surface area.

concentrations in $\mathrm{PM}_{1}$ in cases of Saharan dust episodes observed at the Jungfraujoch. Due to their relatively high vapor pressures, formic and acetic acids are mainly present in the atmosphere in the gas phase, with generally a proportion of a few $\%$ only in the particulate phase (Saxena and Hildemann, 1996). Interactions of these acidic gases with alkaline dust can therefore be expected and heterogeneous reactions are demonstrated in our case also (for formate), with close connection between concentrations and particle surface area (Fig. 10). Concentrations of acetate were not determined in this study, with relatively high concentrations in the field blanks leading to a detection limit at $50 \mathrm{ng} \mathrm{m}^{-3}$.

Conversely, the other acids are generally mostly partitioned in the particulate phase (Saxena and Hildemann, 1996; Ricard, 2001) due to their lower vapor pressure, although Limbeck et al. (2000) found a semi-volatile behavior for some of these compounds. It is likely that correlation between these acids and dust would result from their production directly on the dust from the oxidation of adsorbed gaseous precursors, or from coagulation between dust and submicron particles (where these acids are generally measured). Our data point out to some extent of generation of oxalate on dust by one of these processes, while glutarate was essentially associated with the submicron particles during the anthropogenic episode. This difference can probably result from oxalate being the end product of the oxidation of many organic precursors (Kawamura et al., 1996), more easily transferred to the dust surface in large quantities.

\section{Conclusions}

In this paper, we explore the evolution of some inorganic and organic constituents of the aerosol on a short time scale, in parallel with total mass and number size distribution, during a Saharan dust episode observed in the French Alps in summer 2000. First, the structure of the dust episode was complex, with a large change of the chemical composition of the coarse fraction of the aerosol in the course of the event. Further, the dust event was directly followed by an intrusion of a polluted air mass, with large increases of concentrations in the submicron size range for species from anthropogenic origin. These rapid changes can induce biased in geochemical interpretations in cases of studies of integrated samples (daily aerosol sampling, or ice core records).

Second, the data indicate very low increase of concentrations for sulfate and nitrate associated with mineral dust. Therefore, interactions seem very limited between dust particles and gaseous precursors during transport in the case of this episode, as opposed to many other events described in the literature. Preliminary calculations show that such low concentrations of secondary anthropogenic species are compatible with current knowledge of uptake coefficients of $\mathrm{NO}_{\mathrm{y}}$ and $\mathrm{SO}_{\mathrm{x}}$ on dust particles, under the hypothesis that the dustloaded air mass did not mixed with a polluted air mass during its transport.

Finally, the concentrations of total particulate organic carbon also show limited increase during the dust episode. Only formate presents evolution of concentrations related to that of dust. These observations may indicate low reactions of primary VOC on dust particle, but some extent of uptake of acidic gases like formic acid during transport. 
Acknowledgements. The program POVA is supported in France by Région Rhône Alpes, ADEME (Agence de l'Environnement et de la Maîtrise de l'Energie), METL (Ministère de l'Equipement, des Transports et du Logement), and MEDD (Ministère de l'Ecologie et du Développement Durable), and Primequal 2. We would like to thank Météo France for providing the meteorological data, and l'Air de L'Ain et des Pays de Savoie (Air APS, http://www.atmo-rhonealpes.org/) for TEOM measurements. We would like to thank W. Maenhaut (INW, Gent, Belgium), K. Shure and $\mathrm{M}$. Bergin (Georgia Tech, Atlanta, USA) for access to facilities for EC/OC analyses.

Edited by: A. Petzold

\section{References}

Birch, M. E. and Cary, R. A.: Elemental carbon based method for monitoring occupational exposure to particulate diesel exhaust, Aer. Sci. and Technol., 25, 221-241, 1996.

Boerensen, C., Kirchner, U., Scheer, V., Vogt, R., and Zellner, R.: Mechanism and kinetics of the reactions of $\mathrm{NO}_{2}$ or $\mathrm{HNO}_{3}$ with alumina as a mineral dust model compound, J. Phys. Chem. A, 104, (21), 5036-5045, 2000.

Chin, M. and Jacob, D. J.: Anthropogenic and natural contributions to tropospheric sulfate: a global model analysis, J. Geophys. Res., 101, D13, 18 691-18 699, 1996.

Chuang, P. Y., Duvall, R. M., Bae, M. S., Jefferson, A., Shauer, J. J., Yang, H., Yu, J. Z., and Kim, J.: Observations of elemental carbon and absorption during ACE-Asia and implications for aerosol radiative properties and climate forcing, J. Geophys. Res., 108, D23, 8634, doi:10.1029/2002JD003254, 2003.

Claquin, T. M., Schulz, M., and Balkanski Y. J.: Modeling the mineralogy of atmospheric dust sources, J. Geophys. Res., 104, 22 243-22 256, 1999.

Collaud Coen, M., Weingartner, E., Schaub, D., Hueglin, C., Corrigan, C., Schwikowski, M., and Baltensberger, U.: Saharan dust events at the Jungfraujoch: detection by wavelength dependence of the single scattering albedo and analysis of the events during the years 2001 and 2002, Atmos. Chem. Phys. Discuss., 3, 55475594, 2003,

\section{SRef-ID: 1680-7375/acpd/2003-3-5547.}

Colomb, A., Jacob, V., Debionne, J.-L., Aymoz, G., and Jaffrezo, J.L.: VOC's evolution during a Saharan dust episode in an alpine valley in August 2000, Fres. Environ. Bull., 11, 441-453, 2002.

De Angelis, M. and Gaudichet, A.: Saharan dust deposition over Mont-Blanc (French Alps) during the last 30 years, Tellus, 43B, 61-75, 1991.

Dentener, F. J., Carmichael, G. R., Zhang, Y., Lelieveld, J., and Crutzen, P. J.: Role of mineral aerosol as a reactive surface in the global troposphere, J. Geophys. Res., 101, 22 869-22 889, 1996.

Dhandapani, B. and Oyama, S. T.: Gas phase ozone decomposition catalysts, Appl. Catal. B-Environ., 11, 129-166, 1997.

Echalar, F., Gaudichet, A., Cachier, H., and Artaxo, P.: Aerosol emissions by tropical forest and savanna biomass burning: characteristics trace elements and fluxes, Geophys. Res. Lett., 22, 3039-3042, 1995.

Formenti, P., Andreae, M. O., Lange, L., Roberts, G., Cafmayer, J., Ratja, I., Maenhaut, W., Holben, B. N., Artaxo, P., and Lelieveld, J.: Saharan dust in Brazil and Suriname during the Large-
Scale Biosphere-Atmosphere Experiment in Amazonia (LBA)Cooperative LBA Regional Experiment (CLAIRE) in March 1998, J. Geophys. Res., 106, D14, 14 919-14 934, 2001.

Formenti, P., Elber, W., Maenhaut, W., Haywood, J., and Andreae, M. O.: Chemical composition of mineral dust aerosol during the Saharan Dust Experiment (SHADE) airborne campaign in the Cape Verde region, September 2000, J. Geophys. Res., 108, D18, 8576. doi:10.1029/2002JD002648, 2003.

Galy-Lacaux, C., Carmichael, G. R., Song, C. H., Lacaux, J.-P., Al Ourabi, H., and Modi, A. I.: Heterogeneous processes involving Saharan dust inferred from measurements and model calculation, J. Geophys. Res., 106, D12, 12 559-12 578, 2001.

Goss, K. U.: Effects of temperature and relative humidity on the sorption of organic vapors on quartz sand, Environ. Sci. Technol., 26, 2287-2294, 1992.

Goss, K. U. and Eisenreich, S. J.: Adsorption of VOC's from the gas phase to different minerals a mineral mixture, Environ. Sci. Technol., 30, 2135-2142, 1996.

Goudie, A. S. and Middleton, N. J.: Saharan dust storm events: nature and consequences, Earth Science Reviews, 56, 179-204, 2001.

Hanisch, F. and Crowley, J. N.: Heterogeneous reactivity of gaseous nitric acid on $\mathrm{Al}_{2} \mathrm{O}_{3}, \mathrm{CaCO}_{3}$, and atmospheric dust samples: $\mathrm{A}$ Knudsen cell study, J. Phys. Chem. A, 3096-3106, 2001a.

Hanisch, F. and Crowley, J. N.: The heterogeneous reactivity of gaseous nitric acid on authentic mineral dust samples, and on individual mineral and clay mineral components, Phys. Chem. Chem. Phys., 2474-2482, 2001b.

Hanisch, F. and Crowley, J. N.: Ozone decomposition on Saharan dust: an experimental investigation, Atmos. Chem. Phys., 3, 119-130, 2003a,

SRef-ID: 1680-7324/acp/2003-3-119.

Hanisch, F. and Crowley, J. N.: Heterogeneous reactivity of NO and $\mathrm{HNO}_{3}$ on mineral dust in the presence of ozone, Phys. Chem. Chem. Phys., 883-887, 2003b.

Hanke, M., Umann, B., Uecker, J., Arnold, F., and Bunz, H.: Atmopheric measurements of gas-phase $\mathrm{HNO}_{3}$ and $\mathrm{SO}_{2}$ using chemical ionization mass spectrometry during the MINATROC field campaign 2000 on Mont Cimone, Atmos. Chem. Phys., 3, 417436, 2003,

SRef-ID: 1680-7324/acp/2003-3-417.

Huebert, B. J., Bates, T., Russell, P. B., Shi, G., Kim, Y. J., Kawamura, K., Carmichael, G., and Nakajima, T.: An overview of ACE-Asia: strategies for quantifying the relationships between Asian aerosol and their climatic impacts, J. Geophys. Res., 108, (D23), 8633, doi:10.1029/2003JD003550, 2003.

Jaffrezo, J.-L., Calas, N., and Boucher, M.: Carboxylic acids measurements with ionic chromatography, Atmos. Environ., 32, 2705-2708, 1998.

Jordan, C. E., Dibb, J. E., Anderson, B. E., and Fuelberg, H. E.: Uptake of nitrate and sulfate on dust aerosol during TRACE-P, J. Geophys. Res., 108, D21, 8817, doi:10.1029/2002JD003101, 2003.

Kawamura, K., Kasukabe, H., and Barrie, L. A.: Source and reaction pathways of dicarboxylic acids, ketoacids and dicarbonyls in arctic aerosols: one year of observations, Atmos. Environ., 30, 1709-1722, 1996.

Kirchner, U., Borensen, C., Scheer, V., and Vogt, R.: An FTIR study of soot and mineral dust model compounds and selected reac- 
tions with nitrogen oxides, Proceedings of EUROTRAC Symposium '98: Transport and Chemical Transformation in the Troposphere, Garmisch-Partenkirchen, Germany, 23-27 March 1998, 666-670, 1999.

Li, P., Perreau, K. A., Covington, E., Song, C. H., Carmichael, G. R., and Grassian, V. H.: Heterogeneous reactions of volatile organic compounds on oxide particles of the most abundant crustal elements: Surface reactions of acetaldehyde, acetone, and propionaldehyde on $\mathrm{SiO}_{2}, \mathrm{Al}_{2} \mathrm{O}_{3}, \mathrm{Fe}_{2} \mathrm{O}_{3}, \mathrm{TiO}_{2}$, and $\mathrm{CaO}$, J. Geophys. Res., 106, D6, 5517-5529, 2001.

Liao, H., Adams, P. J., Chung, S. H., Seinfeld, J. H, Mickley, L. J., and Jacob, D. J.: Interactions between tropospheric chemistry and aerosols in a unified general circulation model, J. Geophys. Res., 108, 4001, doi:10.1029/2001JD1260, 2003.

Limbeck, A., Puxbaum, H., Otter, L., and Scholes, M. C.: Semivolatile behavior of dicarboxylic acids and other polar organic species at a rural background site (Nylsvley, RSA), Atmos. Environ., 35, 1853-1862, 2000.

Loÿe-Pilot, M. D., Martin, M., and Morelli, J.: Influence of Saharan dust on the acidity and atmospheric input to the Mediterranean, Nature, 321, 427-428, 1986.

Mori, I., Nishikawa, M., Tanimura, T., and Quan, H.: Change in size distribution and chemical composition of Kosa (Asian dust) aersosol during long range transport, Atmos. Environ., 37, 42534263, 2003.

Ouerdeni, A., Limvorapituk, Q., Bes, R., and Mora, J. C.: Ozone decomposition on glass and silica, Ozone-Sci. Eng., 18, 385416, 1996.

Prospero, J. M. and Savoie, D. L.: Effect of continental sources on nitrate concentrations over the Pacific Ocean, Nature, 339, 687689, 1989.

Putaud, J.-P., Van Dingenen, R., Mangoni, M., Virkkula, A., Raes, F., Maring, H., Prospero, J. M., Swietlicki, E., Berg, O. H., Hillamo, R., and Mäkelä, T.: Chemical mass closure and assessment of the origin of the submicron aerosol in the marine boundary layer and the free troposphere at Tenerife during ACE2, Tellus, 52B, 141-168, 2000.

Putaud, J.-P., Van Dingenen, R., Dell'Acqua, A., Raes, F., Matta, E., Decesari, S., Facchini, M. C., and Fuzzi, S.: Size-segregated aerosol mass closure and chemical composition in Mont Cimone (I) during MINATROC, Atmos. Chem. Phys., 3, 4097-4127, 2003.

Ricard, V.: Aérosols dans l'Arctique Européen: sources, transformations et propriétés optiques, Thèse de l'Universtité Joseph Fourier, Grenoble, France, 345pp, 2001.

Ricard, V., Jaffrezo, J.-L., Kerminen, V.-M., Hillamo, R. E., Sillanpaa, M., Ruellan, S., Liousse, C., and Cachier, H.: Two years of continuous aerosol measurements in northern Finland, J. Geophys. Res., 107(D11), 4129, doi:10.1029/2001JD000952, 2002.
Rodriguez, S., Querol, X., Alastuey, A., Kallos, G., and Kakaliagou, O.: Saharan dust contribution to $\mathrm{PM}_{10}$ and TSP levels in Southern an Eastern Spain, Atmos. Environ., 35, 2433-2447, 2001.

Ryall, D. B., Derwent, R. G., Manning, A. J., Redington, A. L., Corden, J., Millington, W., Simmonds, P. G., O'Doherty, S., Carlaw, N., and Fuller, G. W.: The origin of high particulate concentrations over the United Kingdom, March 2000, Atmos. Environ., 36, 1363-1378, 2002.

Savoie, D., Prospero, J. M., and Saltzman, E. S.: Non-sea-salt sulfate and nitrate in trade wind aerosols at Barbados : evidence for long range transport. J. Geophys. Res., 94, 5069-5080, 1989.

Saxena, P. and Hildemann, L.: Water-soluble organic in atmospheric particles: A critical review of the literature and application to thermodynamics to identify candidate compounds, J. Atmos. Chem., 24, 57-109, 1996.

Schurath, U. and Naumann, K.-H.: Chemical mechanism development: Final Report, ISS EUROTRAC-2 GSF, München, Germany, 2003.

Schwikowski, M., Seibert, P., Baltensberger, U., and Gaggeler, H. W.: A study of an outstanding Saharan dust event at the high-alpine site JungFraujoch, Switzerland, Atmos. Environ., 29, 1829-1842, 1995.

Seinfeld, J. H. and Pandis, S.: Atmospheric Chemistry and Physics: From Air Pollution to Climate Change, Wiley Interscience, New York, 1326, 1998.

Sellegri, K., Laj, P., Peron, F., Dupuy, R., Legrand, M., Preunkert, S., Putaud, J. P., Cachier, H., and Ghermandi, G.: Mass balance of free tropospheric aerosol at the Puy de Dôme (France) in winter, J. Geophys. Res., 109, (D11), 4333, doi:101029/2002JD002747, 2003.

Song, C. H. and Carmichael, G. R.: Gas-Particle partitioning of nitric acid modulated by alkaline aerosol, J. Atmos. Chem., 40, 1-22, 2001.

Swap, R., Ulanski, S., Cobbett, M., and Garstang, M.: Temporal and spatial characteristics of Saharan dust outbreaks, J. Geophys. Res., 101, 4205-4220, 1996.

Talbot, R. W., Harriss, R. C., Browell, E. V., Gregory, G. L., Sebacher, D. I., and Beck, S. M.: Distribution and geochemistry of aerosols in the Tropical North Atlantic troposphere: relationship to Saharan dust, J. Geophys. Res., 91, D4, 5173-5182, 1986.

Ullerstam, M., Vogt, R., Langer, S., and Ljungstroem, E.: The kinetics and mechanism of $\mathrm{SO}_{2}$ oxidation by $\mathrm{O}_{3}$ on mineral dust, Phys. Chem. Chem. Phys., 4, (19), 4694-4699, 2002.

Usher, C. R., Michel, A. E., and Grassian, V. H.: Reactions on mineral dust, Chem. Rev., 103, 4883-4939, 2003.

Zhang, D. and Iwasaka, Y.: Chlorine deposition on dust particles in marine atmosphere, Geophys. Res. Lett., 28, 3613-3616, 2001.

Zhuang, H., Chan, C. K., Fang, M., and Wexler, A.: Formation of nitrate and non-sea-salt sulfate on coarse particles, Atmos. Environ., 33, 4223-4233, 1999. 